\title{
Insulin Binding and Hexose Transport in Rat Adipocytes
}

\author{
Relation to Cell Size \\ J. E. Foley, A. L. Laursen, O. Sonne, and J. Gliemann \\ Institute of Physiology, University of Aarhus, Aarhus, Denmark
}

Summary. Insulin binding, initial velocity of $\left[{ }^{14} \mathrm{C}\right]$ methylglucose transport, uptake of $\left[{ }^{14} \mathrm{C}\right]$ deoxyglucose and conversion of $\left[\mathrm{U}^{14} \mathrm{C}\right]$ glucose to $\mathrm{CO}_{2}$, glyceride-glycerol and fatty acids were measured at $37^{\circ} \mathrm{C}$ in adipocytes from rats of different weights $(135-450 \mathrm{~g})$ and therefore with different mean cell volumes (53-389 pl). Insulin binding per cell increased with increasing cell size and binding was 2.3 times higher in the largest cells than in the smallest cells with tracer alone. The difference was largely accounted for by an increase in the apparent affinity. Influx of methylglucose per cell increased with increasing cell size in the absence of insulin and remained constant as a function of cell size in its presence. The effect of insulin ranged from 11 fold in small cells to 3.5 fold in large cells. The rate of conversion of $\left[\mathrm{U}-{ }^{14} \mathrm{C}\right]$ glucose to $\mathrm{CO}_{2}$ and lipids was about half of the rate of methylglucose transport under all conditions. In contrast, the uptake of deoxyglucose in insulin-stimulated cells decreased markedly with increasing cell size. Increasing cell size caused a small decrease in sensitivity which could be explained by a smaller amount of insulin bound per unit surface area. The results show that increasing cell size/animal weight causes changes in insulin binding which may explain changes in sensitivity. In addition, the hexose transport system is modified in a way which is not explained by changes in insulin binding. Finally, changes in deoxyglucose uptake with cell size do not parallel changes in methylglucose transport.

Key words: Insulin receptors, 3-0-methylglucose, glucose, 2-deoxyglucose, hexose transport, hexose metabolism, fat cell size.

Several authors have investigated the isolated rat fat cell model in the attempt to elucidate the mechanism of the insulin resistance in obesity. Measurement of insulin binding (receptor number and affinity) and hexose transport rates are key elements in such analyses. However, nearly all possible combinations of results have been reported. Thus, Olefsky [1-3] found that binding of $\left[{ }^{125} \mathrm{I}\right]$ insulin per cell decreased as rats grew older and fatter, whereas Lockwood and co-workers $[4,5]$ found no change, and Cushman and Salans [6] an increase. Czech [7] found that transport of tracer hexose (that is in a concentration much lower than $\mathrm{K}_{\mathrm{m}}$ ), when expressed per cell, was several fold higher in large cells than in small cells both in the absence and the presence of insulin. Livingston and Lockwood [8] reported nearly the same transport rates per cell both with and without insulin. Olefsky [2] and Foley [9] found that transport per cell increased with increasing cell size in the absence of insulin but remained approximately constant in its presence.

We undertook the present study in the attempt to resolve these issues by utilising some recent technological improvements. The major element with regard to binding is the finding that a steady state can be maintained for several hours at $37^{\circ} \mathrm{C}[10]$. In addition, we have recently reported that the binding affinity of monoiodoinsulin iodinated in residue A14 (tyrosine) of the A chain is the same as that of insulin, whereas other iodinated derivatives exhibit reduced affinities [11]. With regard to transport, we have recently described a method to measure the initial rate of uptake of 3-O-methylglucose [12], a sugar analogue which is transported at approximately the same rate as glucose but not phosphorylated. This made it possible to measure unidirectional transport of methylglucose in basal and insulin-stimulated cells over the entire size range. We also measured deoxyglucose uptake under the same conditions as those used for methylglucose, deoxyglucose uptake after incubation for 3 minutes, and finally the conversion 


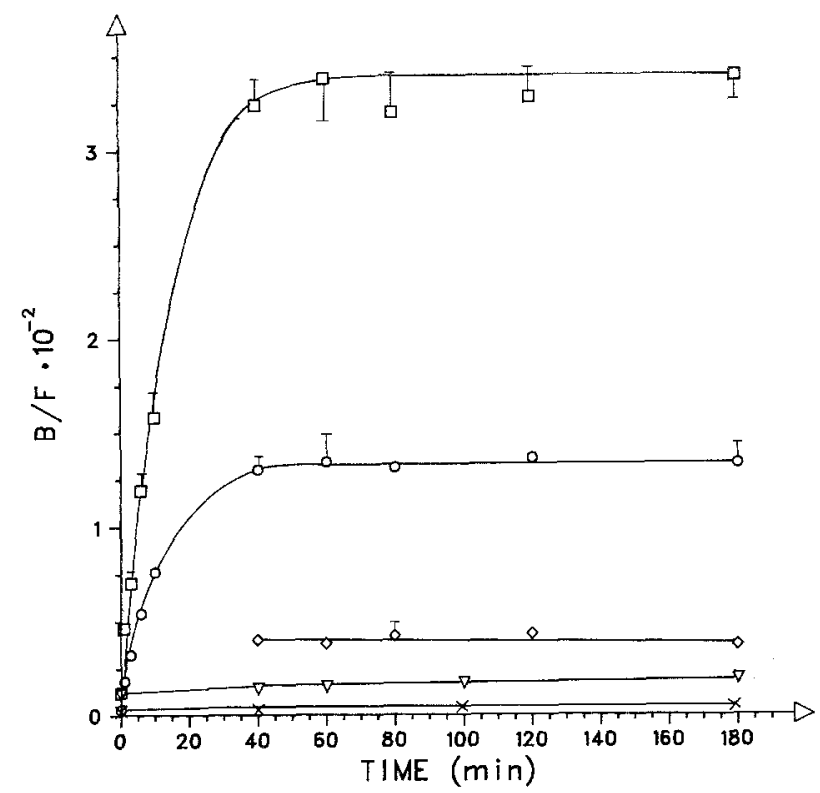

Fig. 1. Time course of binding of $\left[{ }^{125} \mathrm{I}\right]$ iodoinsulin. Adipocytes from a $140 \mathrm{~g}(\mathrm{O}-\mathrm{O})$ and a $430 \mathrm{~g}(\square-\square)$ rat were incubated at $37^{\circ} \mathrm{C}$ with A14-[125 I]iodoinsulin $50 \mathrm{pmol} / \mathrm{l}$. Insulin $10 \mathrm{nmol} / \mathrm{l}$ (small cells, $\diamond-\diamond$ ) or $1 \mu \mathrm{mol} / 1$ (small cells $\times-\times$, large cells $\nabla-\nabla$ ) was added to some samples. All incubations were carried out using $24 \mu \mathrm{l}$ packed cell volume and a total incubation volume of $0.5 \mathrm{ml}$. The number of cells was calculated as described in Methods. The ordinate $(\mathrm{B} / \mathrm{F})$ denotes the ratio: cpm associated with $3 \times 10^{5}$ cells/ cpm in the incubation medium. Extracellular radioactivity trapped in the cell pellet was determined using L-glucose and accounted for a $\mathrm{B} / \mathrm{F}$ of $1.1 \times 10^{-4}$. This value, although negligible, has been subtracted from all points. These are mean values of 4 replicates with 1 SD when this exceeds the size of the symbol

of trace glucose to triglycerides and $\mathrm{CO}_{2}$ after 120 minutes.

The present work represents the first study with concomitant measurements of insulin binding, transport rates of methylglucose and deoxyglucose, and conversion rates of deoxyglucose and glucose at physiological temperature and $\mathrm{pH}$.

\section{Materials and Methods}

Adipocytes were obtained from epididymal fat pads of ad libitum fed male Wistar rats in 3 weight groups: $135-145 \mathrm{~g}, 220-240 \mathrm{~g}$, and $400-450 \mathrm{~g}$. On a given day, experiments were performed on one group of animals using 12,8 , and 3 rats, respectively. HEPES buffer ( $\mathrm{pH} \mathrm{7.4)} \mathrm{with} \mathrm{or} \mathrm{without} \mathrm{albumin} \mathrm{was} \mathrm{prepared} \mathrm{as} \mathrm{described}$ previously [10]. Albumin (bovine, fraction V) was obtained from Sigma (St. Louis, USA), collagenase (type I) from Worthington (Freehold, NJ, USA), pig insulin from Nordic Insulin (Gentofte, Denmark), and phloretin from $\mathrm{K} \& \mathrm{~K}$ laboratories (Plainview, NY, USA). 3-O- $\left[{ }^{14} \mathrm{C}\right]-$ Methyl-D-Glucose $(59 \mathrm{mCi} / \mathrm{mmol}), 2-$ deoxy[l- $\left.{ }^{14} \mathrm{C}\right]$-D-glucose $(54 \mathrm{mCi} / \mathrm{mmol})$, and $\left[\mathrm{U}-{ }^{14} \mathrm{C}\right]-\mathrm{D}$-glucose $(275 \mathrm{mCi} / \mathrm{mmol})$ were from the Radiochemical Centre (Amersham, Great Britain). A14-[ $\left.{ }^{125} \mathrm{I}\right]$ Monoiodoinsulin (about $250 \mathrm{Ci} / \mathrm{g}$ ) was prepared as described previously [11] by Dr. S. Linde, Hagedorn Research Laboratory. The tracer was $98 \%$ precipitable in $12 \mathrm{~g} / 100 \mathrm{ml}$ trichloroacetic acid.

\section{Adipocyte Preparation}

Epididymal fat pads were added to $30 \mathrm{ml}$ polystyrene cylinders containing $3 \mathrm{ml}$ of $3.5 \mathrm{~g} / 100 \mathrm{ml}$ albumin-HEPES buffer with collagenase $0.5 \mathrm{mg} / \mathrm{ml}$ and minced. A $6 \times 15 \mathrm{~mm}$ stir bar was added and the tissue agitated on a magnetic stirrer for $1 \mathrm{~h}$ at $37^{\circ} \mathrm{C}$. The cell suspension was passed through a nylon filter (PES 3000 polymer) and washed 5 times. The fraction of the total volume occupied by the cells was measured in duplicate using haematocrit tubes as described previously [13]. The coefficient of variation was $5 \%(\mathrm{n}=24)$. The cells were then distributed in appropriate amounts to measure binding, transport and metabolism.

\section{Insulin Binding}

Packed cells, $24 \mu$ l, were incubated in a $14 \mathrm{ml}$ polyethylene tube with [ $\left.{ }^{125} \mathrm{~T}\right]$ iodoinsulin $50 \mathrm{pmol} / \mathrm{l}$ and insulin as indicated. The buffer contained albumin $50 \mathrm{~g} / \mathrm{l}$ and bacitracin $0.5 \mathrm{~g} / \mathrm{l}$. The total volume was $0.5 \mathrm{ml}$. It has previously been shown that bacitracin markedly inhibits extracellular insulin degradation without interfering with receptor-mediated degradation of insulin or its effect on hexose transport $[10,12]$. The cells were incubated for $45 \mathrm{~min}$ at $37^{\circ} \mathrm{C}$. The incubation was terminated and the cells recovered as described previously [10].

\section{Transport of Methylglucose and Deoxyglucose}

The initial velocity of uptake was measured using $5 \mathrm{~s}$ incubations in the absence of insulin and $1 \mathrm{~s}$ incubations in cells preincubated for $45 \mathrm{~min}$ with $100 \mathrm{nmol} / 1$ insulin, a maximally stimulating concentration. The incubations were carried out in a room maintained at 37 ${ }^{\circ} \mathrm{C}$ using $40 \mu 140 \%$ (v/v) cell suspension, $12 \mu$ l isotope solution and timing with a metronome as described by Whitesell and Gliemann [12] with minor modifications as described in detail elsewhere [14]. In brief, transport was stopped with $400 \mu 10.1 \mathrm{mmol} / 1$ phloretin, and a $400 \mu \mathrm{l}$ aliquot of the mixture was added to a $550 \mu \mathrm{l}$ microfuge tube containing $100 \mu \mathrm{l}$ silicone oil. The tube was spun within $2 \mathrm{~min}$ in a Beckman microfuge for $30 \mathrm{~s}$, cut through the oil phase and the cell pellet was added to $3 \mathrm{ml}$ counting vial with $2.5 \mathrm{ml}$ scintillation fluid. Zero time was determined by adding $400 \mu \mathrm{l}$ phloretin solution to the isotope solution before adding cells. Under these conditions the extracellular space (zero time space) constituted $6 \%$ of the intracellular water space in the cell pellet. The coefficient of variation on $1 \mathrm{~s}$ measurements (total counts minus extracellular counts) was $5-10 \%$ in small cells and $10-15 \%$ in large cells.

\section{Uptake of Deoxyglucose}

Fifty microlitres of $40 \%(\mathrm{v} / \mathrm{v})$ cell suspension with or without insulin $100 \mathrm{nmol} / 1$ was added to vials containing $950 \mu \mathrm{l}$ buffer with $0.125 \mu \mathrm{Ci} 2-\left[1-{ }^{14} \mathrm{C}\right]$ deoxyglucose. Incubation was carried out in a 37 ${ }^{\circ} \mathrm{C}$ water bath for $3 \mathrm{~min}$, and $15 \mathrm{~s}$ before the end of the incubation a $400 \mu \mathrm{l}$ aliquot was added to a microfuge tube containing $100 \mu \mathrm{l}$ silicone oil and spun for $15 \mathrm{~s}$. Zero time incubations were made by adding cells to vials at $2{ }^{\circ} \mathrm{C}$, immediately followed by centrifugation.

\section{Metabolism of Glucose}

Seven microlitres of packed cells were incubated in a $22 \mathrm{ml}$ beta counting vial with $0.2 \mu \mathrm{Ci}\left[\mathrm{U}-{ }^{14} \mathrm{C}\right]$ glucose and insulin as indicated. The total volume was $1 \mathrm{ml}$ and incubation time $120 \mathrm{~min}$. Incubation was terminated by the addition of $\mathrm{H}_{2} \mathrm{SO}_{4}$, and $\left[{ }^{14} \mathrm{C}^{\mathrm{O}} \mathrm{O}_{2}\right.$ was collected as described previously [15]. Labelled glycerides were 


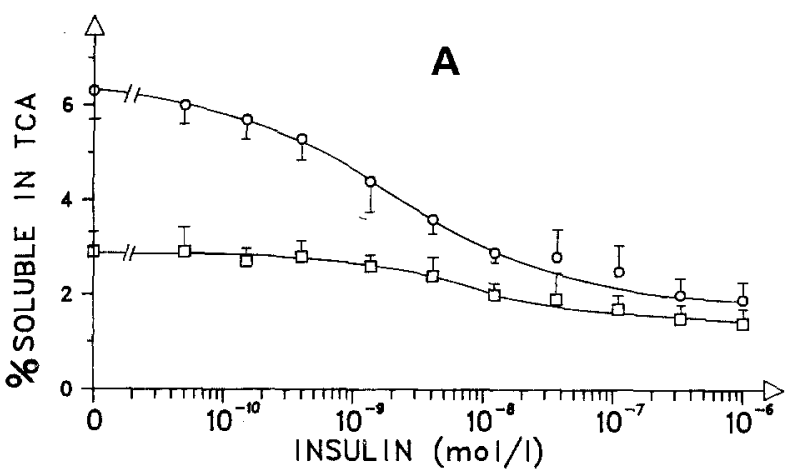

Fig. 2 A-C. Steady state binding as a function of insulin concentration. Small $(O-O)$, medium $(\Delta-\Delta)$ and large $\square-\square)$ cells were incubated as described in the legend to Figure 1 for $45 \mathrm{~min}$ with concentrations of unlabelled insulin as indicated. A Degradation. The ordinate denotes the increase in TCA solubility of $\left[{ }^{125} \mathrm{I}\right]$ iodoinsulin in the incubation medium from $0-45 \mathrm{~min}$. The results are from a representative experiment (mean of 4 replicates) with $1 \mathrm{SD}$. B Binding. The ordinate is the same as that shown in Figure 1. The points on the ordinate indicate binding of the A14-[25 I]iodoinsulin tracer $(50 \mathrm{pmol} / \mathrm{l})$. Each point represents the mean value of 4 independent experiments with $1 \mathrm{SD}$ when this exceeds the size of the symbol. Note that the $\mathrm{B} / \mathrm{F}$ in the presence of insulin $1 \mu \mathrm{mol} / \mathrm{l}$, which we define as non-specific binding, is not subtracted. C Scatchard plots. The data are the same as those shown in Figure 2B. The abscissa denotes bound $\left[{ }^{125} \mathrm{I}\right]$ iodoinsulin plus unlabelled insulin. The ordinate denotes the ratio: mol total insulin bound specifically per $3 \times 10^{5} \mathrm{cells} / \mathrm{mol}$ total insulin $/ 1$ medium. The data of each set of 4 experiments (small, medium or large cells) were normalised in the following way. The ratio of $\mathrm{B} / \mathrm{F}$ (tracer) in each experiment to the mean $B / F$ (tracer) for the group $(n=4)$ was computed and each point in a given experiment was multiplied by this ratio. The points on the graph represent the mean values of the 4 points generated in this way with one vertical and one horizontal SD when these exceed the size of the symbol. Note that SD is not indicated on points with ordinates of less than $0.4 \times 10^{-6}$. The horizontal SD values are very large (more than $2 \times 10^{-14} \mathrm{~mol}$ per $3 \times 10^{5}$ cells) due to the impact of non-specific binding on the scatter of specific binding

extracted using Dole's method and in some experiments the glycerides were saponified and the radioactivity in the glycerol and fatty acid moieties determined [16].

\section{Determination of Cell Number}

One hundred and fifty microlitres of the cell suspension used for measuring glucose metabolism $(0.7 \% \mathrm{v} / \mathrm{v})$ was added to a $10 \mathrm{ml}$ plastic tube containing $0.6 \mathrm{ml} 0.2 \mathrm{~g} / 100 \mathrm{ml}$ osmium tetroxide in $0.154 \mathrm{~mol} / 1 \mathrm{NaCl}$. The cells did not adhere to the sides of the tube and were completely fixed after about $15 \mathrm{~min}$. The diameter distribution was determined [17] from approximately 200 cells
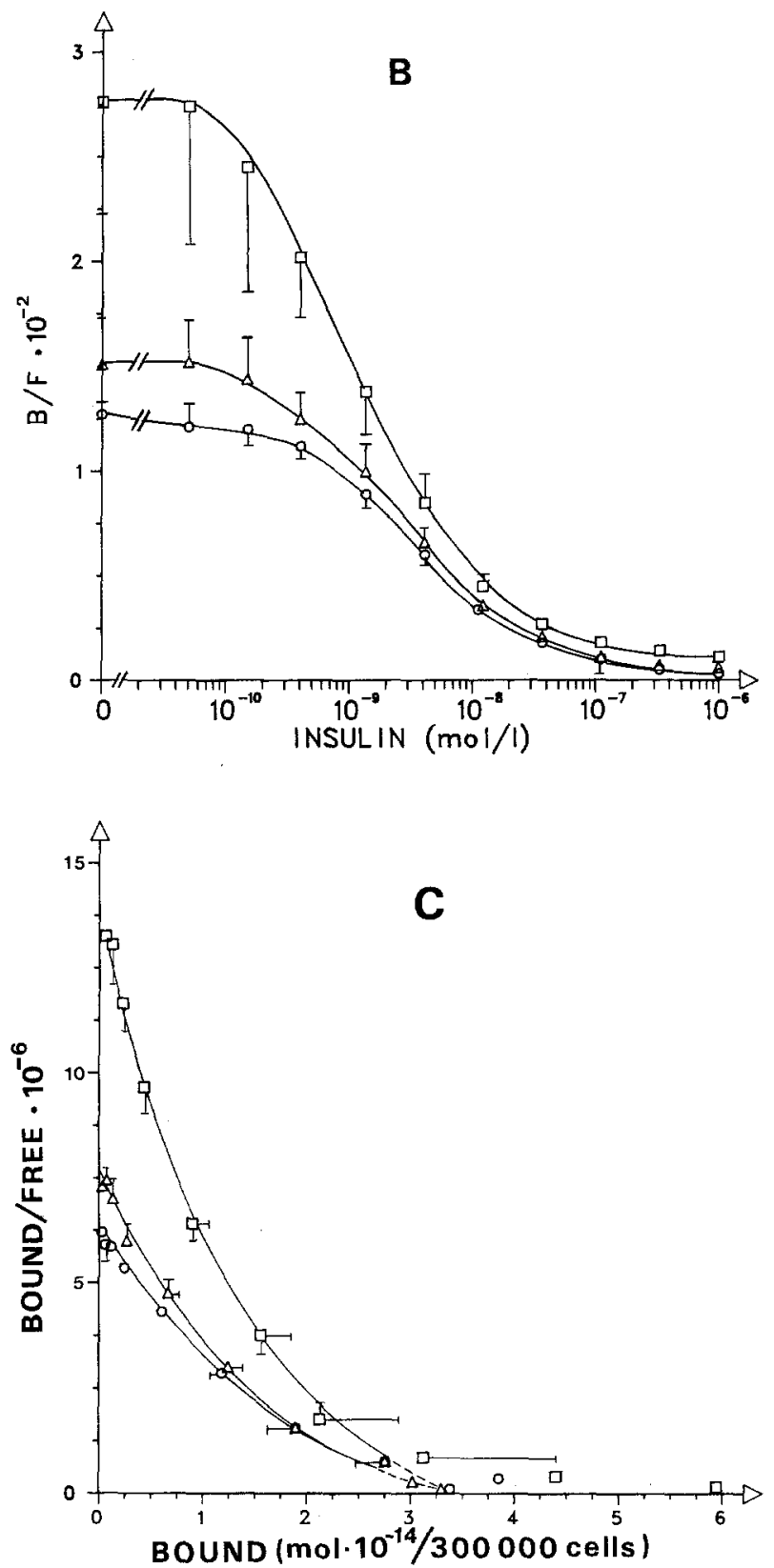

obtained from 3 tubes. The mean diameter was calculated and the mean cell volume determined according to the formula described by Goldrick [18]

$\overline{\mathrm{V}}=\frac{1}{6} \pi\left(3 \delta^{2}+\overline{\mathrm{d}}^{2}\right) \overline{\mathrm{d}}$,

where $\overline{\mathrm{d}}$ is the mean diameter and $\bar{\delta}$ the variance. $\delta$ is a function of the mean cell size and we used previously tabulated values [19] since $\dot{\delta}$ could not be determined with great precision in a sample size of 200 . The number of cells was calculated from the total cell volume and the mean cell volume. The coefficient of variation on 12 measurements was $3 \%$. 


\section{Calculations}

Results are expressed as mean $\pm \mathrm{SD}$. Correlations were calculated using the least square method.

\section{Results}

\section{Insulin Binding and Degradation}

Figure 1 shows that a constant binding was obtained from $40 \mathrm{~min}$ to $180 \mathrm{~min}$, and that non-specific binding, defined as binding of tracer in the presence of insulin $1 \mu \mathrm{mol} / 1$, was only $2 \%$ (small cells) to $4 \%$ of the total binding. Tracer binding per cell was higher in the large cells from old rats than in the small cells; binding per unit cell volume was, however, considerably smaller in the large cells. This phenomenon was observed in 7 other experiments (data not shown). In these experiments some cells were incubated with tracer alone for $45 \mathrm{~min}$, recovered from the oil layer and reincubated in $1 \mathrm{ml}$ buffer with insulin $1 \mu \mathrm{mol} / \mathrm{l}$ at $37^{\circ} \mathrm{C}$ for $60 \mathrm{~min}$. The radioactivity dissociated from the small cells was $49 \pm 8 \%(n=7)$ soluble in trichloroacetic acid, indicating that about half of the receptor bound insulin was degraded in small adipocytes. The value for large cells was $41 \pm 16 \%(n=7)$. In both groups $95 \pm 3 \%$ of the radioactivity was released to the medium by $60 \mathrm{~min}$. Together with the time course shown in Fig. 1, the data demonstrate that the turnover of tracer is nearly the same on receptors from large and small cells.

Figure $2 \mathrm{~A}$ shows that about $6 \%$ of the $\left[{ }^{125} I\right]$ iodoinsulin in the medium was degraded during the 45 min incubation of small cells. A large part of the degradation was inhibited half-maximally by insulin $2-3 \mathrm{nmol} / \mathrm{l}$ suggesting that this degradation is a consequence of insulin binding to its receptor. The high albumin-bacitracin medium, when preincubated with cells for $45 \mathrm{~min}$, degraded only about $1 \%$ of the tracer during a subsequent $45 \mathrm{~min}$ incubation (data not shown). The degradation of tracer was consequently smaller in the large cells which contained fewer receptors per unit volume (Fig. 2A).

Figure $2 \mathrm{~B}$ shows the steady state binding as a function of the insulin concentration for the three groups of rats. The binding per cell was increased in the large cells in the range $50 \mathrm{pmol} / 1$ to about $4 \mathrm{nmol} / \mathrm{l}$. Analyses of the combined data from the 12 experiments showed a highly significant correlation between mean cell volume and tracer binding per cell (increase 2.3 fold over the cell size range, $\mathrm{r}^{2}=0.68$, $\mathrm{p}<0.001$ ). The concentration of insulin causing halfmaximal displacement of tracer (apparent $K_{d}$ ) decreased with increasing cell size. The apparent $K_{d}$

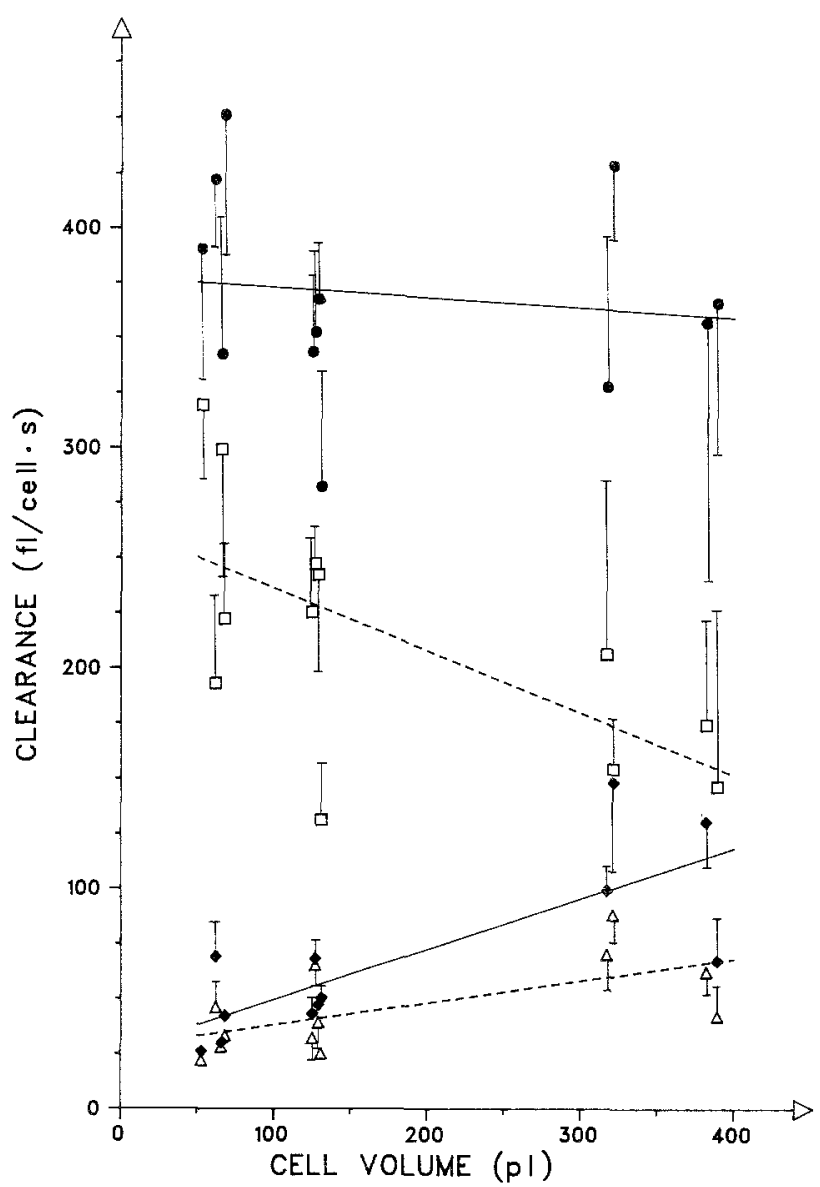

Fig. 3. Initial velocities of methylglucose and deoxyglucose uptake. The results are expressed as clearance rates defined as cpm taken up per cell per s/cpm per fl medium. This expression has the advantage of being independent of the hexose (tracer) concentration when this, as in the present experiments, is much lower than $K_{m}$ for the process which limits the rate of uptake. Basal cells were incubated with $\left[{ }^{14} \mathrm{C}\right]$ methylglucose $(\bullet)$ or $\left[{ }^{14} \mathrm{C}\right]$ deoxyglucose $(\triangle)$ for $5 \mathrm{~s}$ and insulin-stimulated cells were incubated with $\left[{ }^{14} \mathrm{C}\right]$ methylglucose $(\bullet)$ or $\left[{ }^{14} \mathrm{C}\right]$ deoxyglucose $(\square)$ for $1 \mathrm{~s}$ as described in Methods. The points indicate the mean of 4 replicates with $1 \mathrm{SD}$ which includes the variation on the zero time uptake. The following values were obtained with respect to the illustrated regression lines in the presence of insulin: methylglucose clearance $(\longrightarrow)$ on cell volume, $\mathrm{r}^{2}=0.02, \mathrm{NS}$ and deoxyglucose clearance $(---), r^{2}=0.40, p<0.05$. In the absence of insulin: methylglucose clearance, $r^{2}=0.60, p<0.01$, and deoxyglucose clearance, $\mathrm{r}^{2}=0.40, \mathrm{p}<0.05$. Each transport experiment involved determination of the intracellular equilibrium space for methylglucose (i. e. intracellular waterspace). This ranged from 1.3 to $2.7 \mathrm{pl} /$ cell over the cell size range resulting in a increase of the half times of methylglucose uptake in insulin-stimulated cells from about 1.8 (small cells) to $3.6 \mathrm{~s}$

was $3.6 \pm 0.2 \mathrm{nmol} / \mathrm{l}(\mathrm{n}=4)$ for the smallest cells and $1.2 \pm 0.2 \mathrm{nmol} / 1(\mathrm{n}=4)$ for the largest. Regression analyses of the apparent $\mathrm{K}_{\mathrm{d}}$ on mean cell volume $(\mathrm{n}=12)$ gave a decrease to $28 \%$ in the largest cells, $\mathrm{r}^{2}=0.84, \mathrm{p}<0.001$. 
Figure $2 \mathrm{C}$ shows that the Scatchard plots were slightly concave upwards. The initial slopes were well determined by the points corresponding to insulin concentrations of $50 \mathrm{pmol} / 1-1.4 \mathrm{nmol} / \mathrm{l}$, and were significantly steeper for the largest cells (calculated $\mathrm{K}_{\mathrm{d}} 1.0 \pm 0.3 \mathrm{nmol} / \mathrm{l}, \mathrm{n}=4$ ) than for the smallest cells $\left(\mathrm{K}_{\mathrm{d}} 3.1 \pm 0.6 \mathrm{nmol} / \mathrm{l}, \mathrm{n}=4\right)$. Regression analyses of $\mathrm{K}_{\mathrm{d}}$ on cell mean volume $(\mathrm{n}=12)$ gave a decrease to $33 \%,\left(r^{2}=0.74, p<0.001\right)$ in the largest cells. Inspection of the curves suggests that the number of receptors per cell was at least as high in the large cells as in the small cells.

\section{Hexose Transport}

Figure 3 shows that the initial velocity of uptake of tracer methylglucose per cell increased with increasing cell size in the absence of insulin (basal conditions) whereas it remained approximately constant in its presence. Thus the insulin effect decreased from about 11 fold in the smallest cells to about 3.5 fold in the largest. Permeabilities were calculated from the data shown in Figure 3 and the mean surface area. In the smallest cells it was $5.79 \times 10^{-7} \pm$ $1.72 \times 10^{-7} \mathrm{~cm} \cdot \mathrm{s}^{-1}(\mathrm{n}=4)$ under basal conditions, and $5.62 \times 10^{-6} \pm 0.74 \times 10^{-6} \mathrm{~cm} \cdot \mathrm{s}^{-1}(\mathrm{n}=4)$ in the insulin-stimulated state. Regression analyses of the permeability on cell volume $(n=12)$ showed that the permeability remained constant in basal cells (decrease by $16 \%, \mathrm{r}^{2}=0.03$, NS) whereas it decreased by $83 \%$ in insulin-stimulated cells $\left(\mathrm{r}^{2}=\right.$ $0.71, \mathrm{p}<0.001$ ).

The basal deoxyglucose uptake per cell increased as a function of cell volume although the increase was less than that noted for methylglucose. However, the insulin-stimulated uptake of deoxyglucose per cell, in contrast to that of methylglucose, decreased as a function of cell volume.

\section{Hexose Metabolism}

Figure 4 shows that both the basal and the insulinstimulated rate of glucose metabolism was approximately parallel to the methylglucose transport (Fig. 3) over the entire cell size range. The rate of conversion of glucose to $\mathrm{CO}_{2}$ and lipids, which accounts for about $80 \%$ of the rate of glucose uptake $[7,20]$ was about half of the methylglucose transport rate. The data show that the rate of conversion of tracer glucose is a reasonable reflection of the changes in methylglucose transport as a function of cell size, whereas the rate of uptake of deoxyglucose is not.

The ratio of $\mathrm{CO}_{2}$ production to triglyceride synthesis was found to decrease as a function of cell size

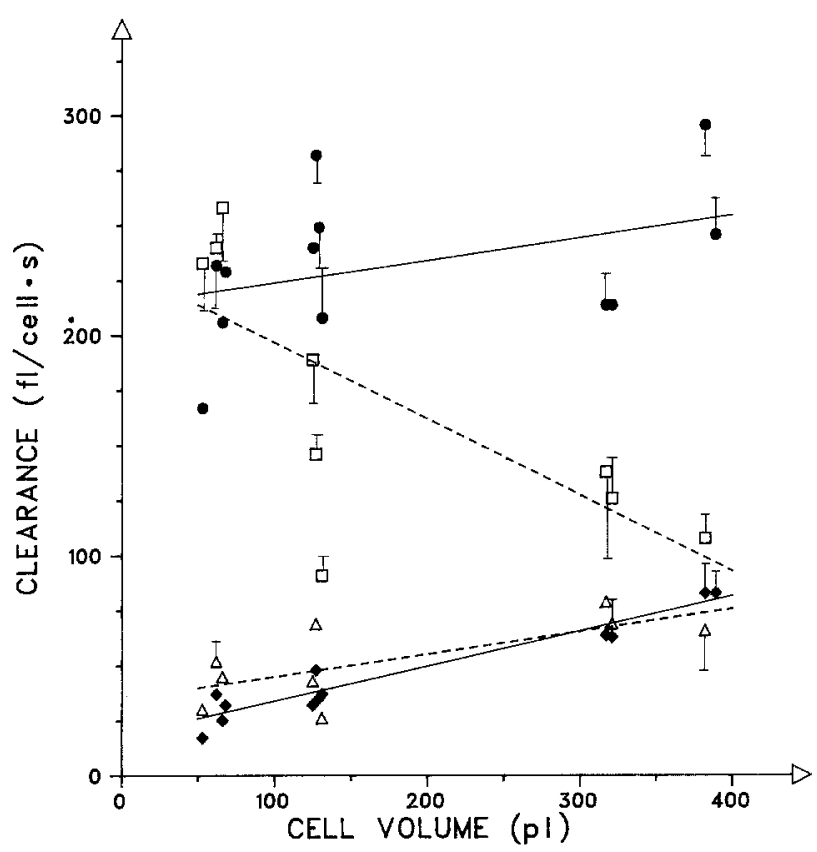

Fig. 4. Rate of conversion of deoxyglucose and glucose. Cells were incubated with $\left[{ }^{14} \mathrm{C}\right]$ deoxyglucose for $3 \mathrm{~min}$ in the absence $(\triangle)$ or presence $(\square)$ of insulin or with $\left[\mathrm{U}^{14} \mathrm{C}\right]$ glucose for $120 \mathrm{~min}$ in the absence ( $)$ or presence ( $)$ of insulin as described in Methods. The points represent the mean values of 4 replicates with 1 SD. Regression lines in the presence of insulin: glucose clearance $(-)$ on cell volume, $\mathrm{r}^{2}=0.15, \mathrm{NS}$ and deoxyglucose clearance $(---)$, $\mathrm{r}^{2}=0.50, \mathrm{p}<0.01$. In the absence of insulin: glucose clearance, $\mathrm{r}^{2}$ $=0.92, \mathrm{p}<0.001$, and deoxyglucose clearance, $\mathrm{r}^{2}=0.50, \mathrm{p}<0.01$

in insulin-stimulated cells. In addition, fatty acid synthesis in the presence of insulin 0-200 pmol/1 was virtually absent in the largest cells (data not shown) as described previously by others $[7,21,22]$.

\section{Insulin Binding and Biological Sensitivity}

Figure $5 \mathrm{~A}$ shows that the sensitivity with respect to glucose metabolism decreased $\left(\mathrm{ED}_{50}\right.$ increased) as a function of cell size. Insulin binding was nearly proportional to the insulin concentration in the biological dose response range (10-150 pmol/l) and binding per cell was higher in the large cells (Fig. 5B). However, the binding per unit surface area decreased slightly as a function of cell size. The mean decrease in binding per $\mu \mathrm{m}^{2}$ in the concentration range $10-150 \mathrm{pmol} / 1$ was $36 \%$ from the smallest to the largest cells. Regression analyses of binding per $\mu \mathrm{m}^{2}$ as a function of cell volume gave $\mathrm{r}^{2}=0.45, \mathrm{p}<0.02, \mathrm{n}$ $=12$. It seemed possible, therefore, that the sensitivity was determined by the number of occupied receptors per unit surface area. Figure 5B shows that the dose-response curves after correction for binding per unit surface area (cf. legend) are superimposable. 

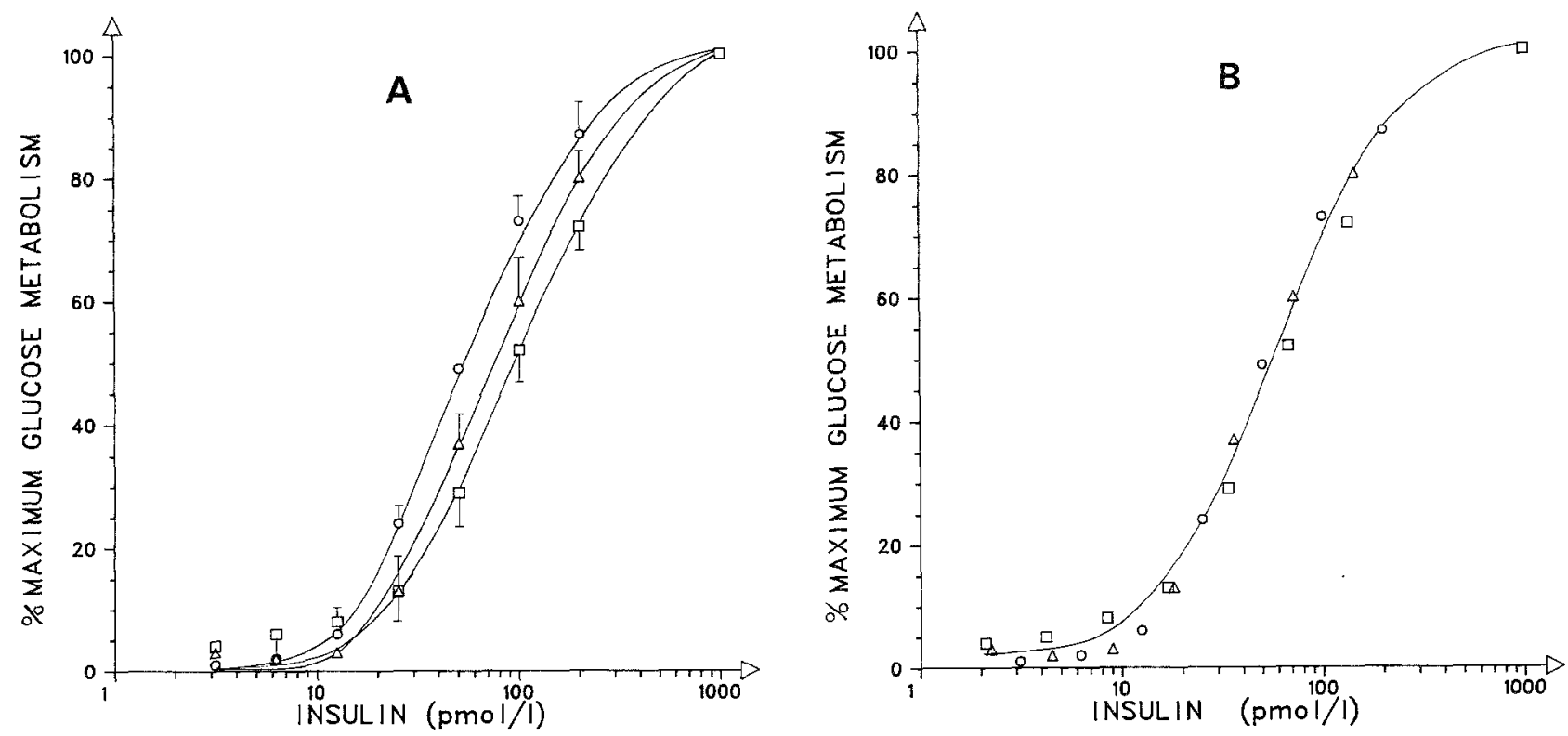

Fig. $5 \mathrm{~A}$ and $\mathbf{B}$. Insulin dose-response relationship. Small $(\mathrm{O}-\mathrm{O})$, medium $(\Delta-\Delta)$ and large $(\square-\square)$ cells were incubated for 120 min with $\left[{ }^{14} \mathrm{C}\right]$ glucose and insulin as indicated. The ordinates show the rate of conversion of glucose to $\mathrm{CO}_{2}$ plus triglycerides in per cent of the maximal conversion rate. The points represent the mean values of 4 independent experiments with 1 SD. The abscissa in panel $\mathbf{A}$ shows the insulin concentrations in the medium. The results in panel $\mathbf{B}$ are identical with respect to the small cells whereas the insulin concentrations for the medium size and large cells are those which would give the same number of occupied receptors per unit surface area as in small cells. This normalization was carried out by multiplying the insulin concentrations of the incubation medium of large (or medium size) cells in panel A with the ratio: tracer bound per unit surface area of large cells/tracer bound per same unit surface area of small cells, where the binding per unit surface area was calculated from the mean cell surfaces (cf. mean cell volumes in Fig. 3) and the binding of tracer per cell (cf. Fig. 2B). This calculation is legitimate because binding was nearly proportional to the insulin concentration in the range considered (Fig. 2B)

\section{Discussion}

\section{Binding}

The present results are different from those reported by Lockwood and co-workers $[4,5]$, who found no change, and are in marked contrast to those reported by Olefsky [1-3] who found a 50 per cent decrease in binding with increasing cell size over approximately the same size range as that studied in the present work. We do not know with certainty the reasons for the differences. We have previously shown that a steady state of binding can be maintained for a prolonged period of time in small cells [10], but this phenomenon has to our knowledge not been reported before in large cells, which are known to be more fragile. It seems possible, therefore, that steady state kinetics have previously been applied in situations where a steady state was not prevailing. The present finding of an increased binding per cell as a function of cell size is in agreement with the results of Cushman et al. [6]. In a preliminary report from this group [23] it was also stated that this increase was mainly due to an increase in affinity. This is again in agreement with our results, but in contrast to those of
Olefsky [1-3] who found no change in the slopes when the data were plotted according to Scatchard.

\section{Transport and Metabolism}

The increase in the basal rate of methylglucose transport per cell as a function of cell size and the lack of change in insulin-stimulated cells was also observed by Foley [9] using L-arabinose at $37^{\circ} \mathrm{C}$. In contrast, Czech [7] reported that the initial velocity of methylglucose transport per cell at $37{ }^{\circ} \mathrm{C}$ was increased by the same factor in basal and insulinstimulated large cells. However, $\mathrm{Czech}$ probably underestimated the transport rates in the presence of insulin (discussed in [12]) since these were less than 10 per cent of the rates of conversion of tracer glucose, which is inconsistent with the affinities of the two sugars for the transport system [12]. Furthermore, this underestimation may have been less marked in the large cells since the half time of methylglucose transport is longer in these cells than in small cells, cf. text to Figure 3. Livingston and Lockwood [8] reported the same uptake of methylglucose per cell both in the absence and presence of insulin. However, these results are difficult to inter- 
pret since no attempt was made to measure transport rates.

The present study shows that deoxyglucose uptake rates do not parallel methylglucose transport rates using incubations for either $1 \mathrm{~s}$ or $3 \mathrm{~min}$ at $37^{\circ} \mathrm{C}$. We have recently demonstrated that in small cells tracer deoxyglucose is transported at a slower rate than tracer methylglucose even though the inhibition constants of the two sugars on the initial velocity of $\left[{ }^{14} \mathrm{C}\right]$ methylglucose uptake are the same [14]. We now show that the difference between insulinstimulated deoxyglucose and methylglucose uptake rates increases as the cell enlarges. This result is in contrast to that of Olefsky [2] who found the same uptake of deoxyglucose ( $3 \mathrm{~min}$ ) per cell in small and large adipocytes. Olefsky used incubations at $24^{\circ} \mathrm{C}$ and this is perhaps the reason for the difference.

The rate of conversion of tracer glucose $(0.7 \mu \mathrm{mol} / 1)$ was proportional to methylglucose transport under all conditions, indicating that transport was rate determining for the metabolism of glucose at this very low concentration. This comparison has not been carried out before but it has been noted by others that transport of glucose in high concentrations is not rate limiting in small or large cells in the presence of insulin $[7,20]$, and that metabolism becomes rate limiting at lower glucose concentrations in larger cells $[4,23]$. The very small effect of insulin in large cells on the rate of conversion of glucose at physiological concentrations is therefore to a considerable extent caused by their low capacity to metabolise glucose [7, 20-23].

\section{Sensitivity}

We observed a small decrease in sensitivity as a function of cell size which disappeared when corrected for the small decrease in binding per unit surface area. Foley [9] using L-arabinose transport and Czech [7] using metabolism of glucose $(0.2 \mathrm{mmol} / \mathrm{l})$ found no detectable changes in sensitivity. However, the changes observed in the present study are so small that the three studies are probably in broad agreement with each other. In contrast, Olefsky $[2,3]$ found a large decrease in the sensitivity with respect to deoxyglucose uptake.

\section{General Implications}

When the rat grows older and fatter the adipocytes enlarge and both the insulin binding system and the hexose transport system undergo changes. Until now we have discussed changes in binding and transport per cell because previous authors have chosen this way of expression. However, it may be physiolog- ically more meaningful to consider the cell surface as the functional unit.

The number of receptors per $\mu \mathrm{m}^{2}$ appears to be roughly inversely proportional to the mean surface area, but at the same time the affinity increases with increasing cell size. As a result, the binding of insulin in low concentrations, including those which cause near-maximal effects on glucose transport [12] and metabolism, is only slightly decreased per $\mu \mathrm{m}^{2}$. Thus, the increase in affinity can be looked upon as a compensatory process. It is unknown how this change is brought about. However, it seems possible that embedding of receptors in a membrane which has undergone more general changes may cause a shift in their affinity. In this connection it is worth noting that receptors of adipocytes from adult man exhibit an even higher affinity than that of the largest rat adipocytes [24].

In previous work [25] we found no evidence for receptor heterogeneity. However, the non-specific binding was for technical reasons much higher than in the present work and the scatter on specific binding became therefore very large at high insulin concentrations (Fig. 2C). The curvilinearity of the Scatchard plots observed in the present work is slight in the sense that $\mathrm{K}_{\mathrm{d}}$ calculated from the initial slope is only about 20 per cent lower than the concentration of insulin causing half-maximal displacement (Fig. 2B and C). The upward concave Scatchard plots are qualitatively in agreement with the finding of others [26]; however, it should also be noted that marked non-linearity can be generated using less suitable experimental designs [10].

Previous work $[12,27]$ has shown that insulin increases $V_{\max }$ of hexose transport without changing the affinity, and recent work by Wardzala et al. [28] suggests that the effect is largely caused by an increase in the number of transport sites. The present data show that transport of $\left[{ }^{14} \mathrm{C}\right]$ methylglucose remains constant per cell (Fig. 3). This implies that the permeability (clearance per unit surface area) in insulin-stimulated cells decreases in inverse proportion to the surface area. The permeability in the absence of insulin remains constant suggesting that the large cells incorporate a higher fraction of the total number of transport sites in the pool available even in the absence of insulin. Consequently, the large cells would be able to recruit less additional sites in the presence of insulin at a maximally stimulating concentration. Insulin at lower concentrations would then recruit a fraction of the additional sites according to the number of occupied receptors per unit surface area. In addition, the finding that the permeabil- 
ity to deoxyglucose in the presence of insulin decreases more than the permeability to methylglucose and glucose as a function of cell size (Fig. 3) suggests that the properties of the transport system change with increasing cell size in another as yet undefined manner.

Acknowledgements. This work was supported by Juvenile Diabetes Foundation, Nordic Insulin Foundation and Danish Medical Research Council. The excellent technical assistance by Rosemary Foley, Thomas Røll Larsen and Inge Pedersen is gratefully acknowledged. We also wish to thank Dr. Samuel Cushman for his helpful suggestions during this study.

\section{References}

1. Olefsky JM, Reaven GM (1975) Effect of age and obesity on insulin binding to isolated adipocytes. Endocrinology 96: 1486-1498

2. Olefsky JM (1976) The effects of spontaneous obesity on insulin binding, glucose transport and glucose oxidation of isolated adipocytes. J Clin Invest 57: 842-851

3. Olefsky JM (1976) The insulin receptor: Its role in insulin resistance of obesity and diabetes. Diabetes 25: 1154-1165

4. Livingston JN, Cuatrecasas P, Lockwood DH (1972) Insulin insensitivity of large fat cells. Science 177 : $626-628$

5. Lockwood DH, Livingston JN, Amatruda JM (1975) Relation of insulin receptors to insulin resistance. Fed Proc 34: 1564-1569

6. Cushman SW, Salans LB (1975) Dissociation of insulin binding from the metabolic response to insulin in isolated rat adipose cells. Endocrinology 96 (Suppl): 92 (abstract)

7. Czech MP (1976) Cellular basis of insulin insensitivity in large adipocytes. J Clin Invest 57: 1523-1532

8. Livingston JN, Lockwood DH (1974) Direct measurement of sugar uptake in small and large adipocytes from young and adult rats. Biochem Biophys Res Commun 61: 989-996

9. Foley JE (1976) L-arabinose transport in isolated rat adipose cells. Thesis, Hanover, N. H.

10. Gliemann J, Sonne O (1978) Binding and receptor-mediated degradation of insulin in adipocytes. J Biol Chem 253 $7857-7863$

11. Gliemann J, Sonne O, Linde S, Hansen B (1979) Biological potency and binding affinity of monoiodoinsulin with iodine in A14 or A19. Biochem Biophys Res Commun 87: 1183-1190

12. Whitesell RR, Gliemann J (1979) Kinetic parameters of transport of 3-O-methylglucose and glucose in adipocytes. J Biol Chem 254: 5276-5283

13. Gliemann J, Østerlind K, Vinten J, Gammeltoft S (1972) A procedure for measurement of distribution spaces in isolated fat cells. Biochim Biophys Acta 286: 1-9
14. Foley JE, Foley R, Gliemann J (in press) Rate limiting steps of 2-deoxyglucose uptake in rat adipocytes. Biochim Biophys Acta

15. Gliemann J (1967) Assay of insulin-like activity by the isolated fat cell method I. Factors influencing the response to crystalline insulin. Diabetologia 3: 382-388

16. Moody AJ, Stan MA, Stan M, Gliemann J (1974) A simple free fat cell bioassay for insulin. Horm Metab Res 6: 12-16

17. Gliemann J, Vinten J (1974) Lipogenesis and insulin sensitivity of single fat cells. J Physiol (Lond) 236: 499-516

18. Goldrick RB (1967) Morphological changes in the adipocyte during fat deposition and mobilization. Am J Physiol 212: 777-782

19. Di Girolamo M, Mendlinger S, Fertig JW (1971) A simple method to determine fat cell size and number in four mammalian species. Am J Physiol 221: 850-858

20. Gliemann J (1968) Glucose metabolism and response to insulin of isolated fat cells and epididymal fat pads. Acta Physiol Scand 72: 481-491

21. Olefsky JM (1977) Mechanisms of decreased insulin responsiveness of large adipocytes. Endocrinology 100: 1169-1177

22. Richardson DK, Czech MP (1978) Primary role of decreased fatty acid synthesis in insulin resistance of large adipocytes. Am J Physiol 234: E182-E189

23. Cushman SW, Zarnowski MJ, Franzusoff AJ, Salans LB (1978) Alterations in glucose metabolism and its stimulation by insulin in isolated adipose cells during development of genetic obesity in the Zucker fatty rat. Metabolism 27 [Suppl 2]: $1930-1940$

24. Andersen O, Gliemann J, Gammeltoft S (1977) Receptor binding and biological effect of insulin in human adipocytes. Diabetologia 13: 589-594

25. Gammeltoft S, Gliemann J (1973) Binding and degradation of ${ }^{125} \mathrm{I}$-insulin by isolated fat cells. Biochim Biophys Acta 320: $16-20$

26. Kahn CR (1976) Membrane receptors for hormones and neurotransmitters. J Cell Biol 249: 2249-2257

27. Vinten J, Gliemann J, Østerlind K (1976) Exchange of 3-Omethylglucose in isolated fat cells. Concentration dependence and effect of insulin. J Biol Chem 251: 794-800

28. Wardzala LJ, Cushman SW, Salans LB (1978) Mechanism of insulin action on glucose transport in isolated rat adipose cells. Enhancement of the number of functional transport systems. J Biol Chem 253: 8002-8005

Received: December 31, 1979,

and in revised form: April 28, 1980

Dr. J. Gliemann

Institute of Physiology

University of Aarhus

Universitetsparken

DK-8000 Aarhus C

Denmark 